\title{
POLITICS AND FOLK RELIGION: CONCEPTS AND PROBLEMS
}

\author{
Gábor BARNA \\ Department of Ethnology, University of szeged \\ Egyetem u. 2, H-6722 Szeged, Hungary
}

\begin{abstract}
The paper deals basically with the mutual interference of politics and religion. It gives a short historical overview based on European and Hungarian examples and tries to shape the dominance of them in different ages and fields (heretic movements, Reformation, Counter-Reformation, spiritual movements, Christian politics, political Catholicism, etc.). It describes how religious symbols or quasi-religious symbols can be/are used in politics as expressions for social and power efforts. It is dealing with the role of religion in nation-building in the past and present, with the role and formation of religious parties, of national and political myths. Politics has an important role in the re-christianization of Europe in the last decades, which can be observed not only in the post-communist countries, but elsewhere in Europe, too. Politics, political movements and ideologies (e.g. feminism) influence the everyday life of churches, causing debates and conflicts in governing church institutions. Religious movements can express and symbolise new ambitions and interests of given social strata and they can institutionalize, handle and conduct social conflicts (e.g. veneration of Jesus Heart). Religions and churches play an important role in the post-revolutional transition of Eastern Europe. Religion can legitimize social effort, can express national(istic) thoughts, conflicts (e.g. former Yugoslavia, Armenia, today Romania, Northern Ireland, Scotland) or social tolerance (Switzerland, today Hungary, etc.). Religion has played an important role in colonialization, having built new traditions, protecting given efforts and interest. But religion played an important role also in decolonialization. Religion can be a basis of social pillarization also in the age of secularization. Secularization processes in the late 20th century politics are no de-sacralization processes at the same time. Secular movements, because they need legitimation, use signs, symbols which often can be found in religious symbolism (communist movements and parties, neo-pagan movements, etc.). The paper tries to interpret the secularization process. In my interpretation it is a privatization process of religion(s) and as result of the process emerges an individual/invisible religiosity.
\end{abstract}

Keywords: politics, religion, folk religion, religious movements, religious symbols, religion and society, secularization, individual religiosity, Eastern Europe, Europe

Politics and religion. Phenomena seemingly very remote from each other.

Politics and folk religion. The difference between these appears to be even greater since 'folk religion' is generally much more weakly institutionalized than 'religion' in general, which, through its institutions, may have links to the institutions of politics and through the movement of the social structure may also be part of the processes of social change.

I would like to give a general overview in the light of our Conference of the links between these two areas, their problems and concepts as a possible approach to the topic.

The research is supported by the research project No. T 026494 OTKA (National Scientific Research Fund). 
What is politics? According to a synthesis of the various interpretations, politics, is the sum of actions and institutions aimed at obtaining the decisive, leading roles (dominance) within small and large communities and between communities, in other words, at winning power, and at retaining it, and expressing and representing interests. The views on the methods for obtaining, using and retaining power are expressed in ideology (GEERTZ 1994a; ZENTAI 1997: 26-29). Politics is thus a special area of social relations and is specifically characterized by the manifestation of power and prestige. Politics needs, or may need, religious legitimation (MOL n.d.: 117). Behavioural constraints operate in the actions of homo politicus and abstract words, views, opinions and convictions, myths, fears, desires and aggressions, wills, role expectations and social norms are also present. All this represents a scheme of interpretation on which people base their actions (EDELMAN 1972: 31 cited in SZABÓ 1998: 113; ZENTAI 1997: 11).

This symbolic interpretation of politics appears relevant for the problem chosen as the theme of our Conference, rather than other possible interpretations (semantic, pragmatic, rhetorical, and communicative-discursive). Putting this in the simplest terms, everyday phenomena, events, expressions and things not only mean something but also acquire 'significance'. That is, they become special vehicles of meaning. The use of symbols is a widespread phenomenon at all levels of political life. It is sufficient to think of the material symbols (badges, coats-of-arms, buildings, posters, etc.), the actions (demonstrations, elections, political celebrations, conflicts and their management, etc.), and the conceptual language used, all of which are condensed signs, always referring to something else as well. The symbols also contain emotions and wills. Their main function is to integrate and orientate (SZABÓ 1998: 95). Their use is very strongly linked to culture (SZABÓ 1998: 96). Politics must provide an answer on the nature of the world order (good - bad, self images and other-images), the legitimacy of power, the resolution of conflicts and shaping the future image of groups affecting the whole of society or forming part of the society. (ZENTAI 1997: 12).

This is similar in content to the religious scheme of interpretation of the world. Important features of political myths include simplification, personification and the bipolar attitude. Practically the same determinants are found in religious interpretation too (SZABÓ 1998: 111 ff.). However, phenomena can only be interpreted in the given cultural context. They have a strong emotional charge.

What is religion? Most definitions of religion are based on the distinction between the supernatural and the natural. In other words, on a distinction between the sacred and the profane. But the texts, objects, persons, actions, institutions, etc. of religion(s) operate within a social structure.

Religion deals with sin, death and the fragility of public life. It pulls towards principles, virtues, ideals, and perfection. Politics, on the other hand, demands compromise, civility, secularity, and plurality. How then, are religion and politics to be related? They are not to be separated, as classical liberal theory implies, nor are they to be collapsed into each other, as theocratic or civil religion models propose. Rather, they are to interact at their overlapping and moving borders. 
And what is the folk religion that figures in the title of our Conference? The definitions of folk religion found in the history of science can be divided into several groups. 1. "Folk religion is the totality of all those views and practices of religion that exist among the people apart from and alongside the strictly theological and liturgical forms of the official religion." (YODER 1974: 14). This definition is largely followed in the Hungarian literature too by Sándor BÁLINT. (BÁLINT 1987: 10). 2. According to others, the religion of the 'people' is the religion of social groups far removed from the mainstream of official church and social processes (BRUNVAND 1996: 620). 3. The concept of folk religion as opposed to the culture of the elite is especially popular among a group of social historians and historical anthropologists. (BURKE 1985; for a critique of this see: FreITAG 1991). 4. Leonard Norman Primiano calls folk religion 'vernacular religion' and, like the first group of definitions, defines its content quite broadly. "Vernacular religion draws attention to religious beliefs, practices, and experiences as they are understood, undertaken, and expressed by all people, modern and traditional, urban and rural" (BRUNVAND 1996: 620). The opposition that appears in this definition is between an ideal of religion the institutional, codified, set form of religion - and religion as experienced (BRUNVAND 1996: 620-621).

Seen in historical perspective, there is a wide range of countries where the religious phenomenon plays an important role (e.g. Israel, tribal states). The papers dealing with India at our Conference (Hiriyanna, Korom) show the important organizing role of religion in the life of tribes and castes, the leading role of the priesthood in directing particular tribes, the use of local cults in everyday life, or the conscious use made of religious and quasi-religious symbols in the political activity around elections in regions with many different religions and many different cultures. In other countries religion played or plays a relatively small role (former USSR, socialist countries). This has also been the case historically. According to HUNTINGTON, the tensions are found along the differences between civilizations that are also determined by religion (HUNTINGTON 1998; also cited by KALLSCHEUER 1996: 23; BARNA 1998). This view also lies behind the history of philosophy conceptions on Central Europe (BARNA 1998; LENDVAI 1997). Multiethnic co-existence based on religious tolerance is less popular, less accepted today. (KALLSCHEUER 1996: 18). Besides, this could only be achieved where there was a relative balance of peoples and denominations, that is, where none was in a position of dominance over the others.

The appearance of religion and the supernatural in politics can be observed in three areas: 1. government may be based directly on religion, as in a theocracy, 2. religion may give legitimacy to the power of the ruling elite, 3 . religion may support the structures, formations and traditions that can be manipulated by those in power (LEWELLEN 1983: 66). The papers presented at our Conference are about this too, particularly the latter area.

According to researchers of religion one of the characteristics of social happenings of the past two centuries and the present time is that religion and its institutions are occupying an ever smaller and more marginal place in the social structure. This 
is the process of secularization. It seems to me that one possible approach to the link between 'politics' and 'folk religion' is in essence the interpretation of the process of secularization.

One basic question in connection with the secularization of recent centuries is: what is the role of religion in today's western society and what cultural forms has it assumed? While in the modern world religion has gradually become a 'private affair', withdrawing to the area of the private sphere, globalization as an important cultural and economic process has transformed the whole society into practically a 'global village'. What role has been played and can be played by religion in this? Does it act within the process or remain outside it? Is it really true that religion basically operates outside the social structure? Is this why researchers on society and culture in Hungary, for example, devote little attention to religion?

It does in fact seem that religion and its institutions are in a marginal position in the structure of today's society compared to the dominantly secularized institutions.

It can be said that the concept of individualization appearing in secularization, and the concomitant values of human rights, freedom, participation in the economic and political processes, and social justice all expressed in the concept of democracy coincide with the basic Christian notions of sacrality and human values and have been incorporated into the general European religious culture. On the other hand, while proclaiming the moral autonomy of secular political activity, politics recognizes that political culture has religious links (KOKOSALAKIS 1993: 135). The process supported by European Christianity shaped the demand and right to the private sphere (CASANOVA 1996: 188). Examining the religious changes in Hungarian society of the 1980s, Miklós TOMKA, sociologist of religion, was able to describe two related processes: 1 . secularization, and 2 . a process of de-secularization, that is, when religion emerges from the state of repression and rebuilds its institutions, permeating a part of social/political life (TOMKA 1988: 76). In the former socialist countries behind the Iron Curtain, the churches were practically the only stable ideological and organizational institutions during and after the political change. This is why their significance grew in the course of the political changes. As a result, a religious revival could also be observed in Hungary and elsewhere (KALLSCHEUER 1996: 19). In the world freed from the domination of totalitarian ideologies and marked by increasing individualization and privatization, the pluralism of values and interests was also manifested in the adoption and/or creation of numerous new religious communities and movements (see: BARNA 1999).

These findings can also be regarded as my paper's points of departure.

In modern societies religion is present in the social structure to a far less extent than it was in earlier societies. At the same time, it is an increasingly accepted opinion that religion cannot be considered only in its institutionalized forms. We know from practical experience that the 'religious' is present even without social institutionalization, as folk religion, as new religious movements, as individual religiosity or desacralized rites, etc. In short, religion cannot be restricted to its institutionalized forms. Examining German politics and the religious dimensions of political culture in the 1980s, Rolf SCHIEDER wrote that religious symbolism was returning to politi- 
cal life and the world of political discourse (SCHIEDER 1987: 294 ff.). The same thing can be seen in Hungarian politics in the 1990s. In 1990-1994 our first democratically elected government consciously built on this language of religious symbolism, while in 1994-1998 the socialist (in reality returned communist) and extreme left-wing liberal coalition rejected this at the level of social discourse, although it supported its own power with quasi-religious symbols. The present bourgeois liberal and conservative parties which have been in power since 1998 consciously accept - although with differing emphases - both religious legitimation and the use of 'political religion' drawing on Christian traditions.

What then is religion? Religion can be conceived in general (and from the anthropological and perhaps also sociological viewpoint) as a dynamic cultural phenomenon, the embodiment of values, contents, feelings and symbols (MARTIN 1978: 13, - cited in KOKOSALAKIS 1993: 136). In this symbolical cultural interpretation, religion is directly linked to the fundamental existential interpretation of human conditions, to the notions people form of justice, freedom, good and bad. (KOKOSALAKIS 1993: 136; GEERTZ 1994b). The values accepted by society are often personified. The saints, individuals practising Christian virtue to a heroic degree, offered in the past and present life models that should or could be followed. In politics, too, there is a kind of secularized 'cult of saints' directed at political leaders, founders of parties, etc., which bears many of the external signs of religious cults. Various 'values' and interests are manifested in this, becoming patterns to be followed or simply ideal types. This can be seen very strikingly in the 19th-20th century workers' movement and in the 20th century totalitarian ideologies (celebrations, portrayals, 'cult of relics' - mausoleums, etc.) (See KORFF 1976). A similar cult emerged after the death of Princess Diana (see Marion Bowmans' paper in this volume), and appears on the anniversary of her death. The different sets of values are present in everyday life as alternatives and people are attracted or repelled by them. In essence, such debating (religious and profane) sets of values are reflected in the political rhetoric of the Norwegian home mission (see Amundsen's paper in this volume).

According to Durkheim and Weber, the causes of changes in religions must be sought in changes in the structure of society. In this view, the marginalization of religious institutions reflects the decline of religion in society. But is this really true?

In the western world the magical conception of the world and the power of priests/churches have, in fact, declined in significance. But ideologies, including here the 18th century Enlightenment as well as those related to democracy in general, have never lost their metaphysical underpinnings. For they are based on faith and hope. Rationalism itself can never be purely rationalist (KOKOSALAKIS 1993: 137). In other words: besides a rationality of purpose (Zweckrationalität) there also exists a rationality of value (Wertrationalität). According to the Weberian conception, even behind the entirely rationally interpreted, governable conception of the world, there must be a unique quasi-religious logic and characteristic. And even if ideology and religion are not the same thing, they are very closely related. The organization of modern economic life, the system of political institutions and social life is not based 
only on rationality and rationalization. These processes cannot dispense with the essence of religion either. In this way modern society shapes its own religious processes and forms. (KoKOSALAKIS 1993: 138).

The question is: if religion remains in today's society, what is its social form/manifestation, and how are these forms related to the system/structure of society? Despite the existence of a process of secularization, it can be said that in recent decades religion has not ceased to exist, it has not yet disappeared even in the developed western states and democracies. Indeed, we can observe a kind of revival of popular religion, as well as various forms of new religious movements, charismatic religions (see BARNA 1999), occultism and New Age phenomena (KOKOSALAKIS 1993: 139) which are being further strengthened by the mood of waiting for the end of the world that surrounds the millennium. A distinctive religious transformation is taking place at subjective level (KOKOSALAKIS 1993: 139).

At the end of the 1960s (1967) Thomas LUCKMANN wrote his book titled 'Invisible Religion', in which he regards religion as a comprehensive anthropological category. He concludes that in modern societies religion has shifted from the collective level and consciousness, to the subjective and private sphere. In other words, Luckmann noticed that religion in the modern age has broken away and escaped from the social system (KOKOSALAKIS 1993: 139). But this detachment is only one of appearance. Just as there is no personal language, so we cannot speak of a strictly only private/individual religiosity. Or another example, individual liberty can only be a product of collective work - in other words: can only be collectively secured and guaranteed (BAUMAN 1997: 7). Luckmann's theory of 'invisible religion' is based on the assumption of a crisis of the institutional apparatus, [but] seems to be applicable only in certain cases, and does not destroy so-called church religion (CIPRIANI 1984: 30).

Church religion was able to strengthen beside individual religion.

In the 1980s and 1990s there has been an increase in the political significance of religion and religious fundamentalism. It became a decisive factor in conflicts in the Middle East, in the contradiction between Jews and Islam, and in the strengthening of fundamentalism in Iran, Afghanistan, Algeria and Dagestan. It is continuously present in Europe, in the Yugoslav conflict, and also in Transylvania where the Romanian Orthodox Church does not wish to relinquish its dominance as the state religion. The 'democratic' government is still not willing to return the properties confiscated at the beginning of the communist period from the western Christian churches (Greek Catholic, Roman Catholic, Calvinist, Unitarian), but continues to support Orthodoxy. Another dimension lies behind this: the structuring and strengthening of the national identity.

All this indicates that the individualization and privatization of religion has not taken place, or not in the way that certain theoreticians believed they could see in the past decades, even though the theory of the privatization of religion is in line with the essence of western cultural development which gave the individual sovereign status. But this sovereign individualism became general and generally institutionalized in the western societies. One of the stimulants of modern individualism 
was Christianity itself (KoKOSALAKIS 1993: 140). At the level of community politics, personal religion is much more closely related to the feeling of democracy itself, and to the demand for individual and community autonomy and identity. Consequently, religion was able to return to the community arena at the level of both liberal and conservative politics. This can be seen in the political activity based on Christian values, and in the vigorous spread of new Christian movements from the USA to Europe and the whole world. This process can be strengthened by the growing dominance of Islam present in European societies to a growing extent, generating some kind of collective Christian response (KoKOSALAKIS 1993: 141). This can be seen in the democratic political life being reorganized after the world-wide collapse of totalitarian atheistic regimes (from Russia through Albania to Cuba). This is why CIPRIANI, on the basis of the Italian example, proposes introduction of the concept of 'diffused religion' (CIPRIANI 1984).

The privatization of religion is definitely related to the question of collective cultural and political rights and permeates society (CIPRIANI 1989, also cited in KOKOSALAKIS 1993: 141). In practice this means the spread of various forms of popular religion. The generally prevailing view is that modernity and popular religion are incompatible concepts and mutually exclusive aspects of social reality. There can be no doubt and it can be observed everywhere that the mediaeval magical thinking has basically lost its significance, but below the surface, there has always been a great variety of popular religion which was either tolerated or rejected by the institutionalized church and the state. An example in Hungary is the movement of Marian priests, the charismatic movement.

To a certain extent these social phenomena have in turn influenced theological thinking. While in the 1960s and 1970s the church wanted to modernize and 'demythologize' religion, from the 1980s the aim was to stress the link between moral and religious values. The efforts of the church and religion for modernization and rationalization in a way resembled the similar efforts made in the 19th century, that is, to suppress popular religion, strengthen ecumenism and curb the cult of Mary and the saints that was weakening it. A striking example of this is the practice observed in the 1990s in organization of the church feast in Szeged Lower Town (See PUszTAI 1999). Here, on the feast of the Blessed Lady of the Snows, in 1997 for example, there was no mention of the veneration of Mary, of the feast of the Blessed Lady of the Snows and its symbolical content, the organizers did not allow the small groups representing popular religion still present sporadically to have a say, but instead involved them immediately in the organized and official liturgy (mass, adoration, litany). This obvious tension led to a shrinking of the previously wide region from which this place of pilgrimage had attracted pilgrims and it became of local significance only.

The strong feminist movements that emerged parallel with the growth in the role of the individual brought the application of feminist viewpoints in all areas. While this is not yet the case for Hungary, in most countries of Western Europe feminist theology, a feminist interpretation of the Bible, etc. are no longer unaccustomed phenomena. The social/political movement has in turn influenced religious 
thinking and theology. One sign of this was the strengthening of the veneration of Mary and the female principle that could be observed in the Swedish Church. I saw that portrayals of Mary are appearing in more and more Protestant churches, a sign that women want to play a role in the church, too. Another sign is the ordination of women as ministers in a number of Protestant churches (England, Germany, Hungary, etc.), giving rise to many debates and splits within the churches concerned. The paper presented by Katarina Lewis deals with women's roles and presence, with the confrontation between the Christian and modern conceptions of society in the Swedish Lutheran Church, the conflict between traditional female social roles and modern self-fulfilment. Under different social circumstances, for example in former Soviet Karelia, the role of women increased and it became their task to defend and pass on the faith, and to spread anti-communist, anti-atheist and anti-technology propaganda in their own families. This increased role of women declined after the political change and the male-centric church image strengthened again. Leonard Primiano writes about the religious practice of homosexual and lesbian believers, people the church previously did not know where to place.

The rapid changes that have occurred in the lives of individuals and small and large communities (emigration, changes of political regime $=$ changes in the set of values), or the recurring economic crises of our times can also cause psychological insecurities. These demand a kind of religious security. Margaret Mackay speaks in her paper of the role played in the past and present by Calvinist hymns as a vehicle and expression of values. This psychological insecurity is probably also a factor behind the strengthening of religious fundamentalism. The growth of religiosity in the various forms of popular religion can certainly also be of political significance at different levels, even if these forms are not part of the political structure of society. A number of papers deal with these aspects: the institution of monarchy, the link between civil religion and folk religion (Rowbottom), a distinctive religious practice and way of life developed under the totalitarian atheist autocracy (Küllós). Thus, despite the marginalization of religious institutions and the obvious autonomy of the basic institutions, religion and popular religiosity also appear in socio-economic and political contexts (KOKOSALAKIS 1993: 142).

It seems to me that the introduction of the concepts of 'civil religion' and 'political religion' and the interpretation of their phenomena is a relevant formulation of this duality. The idea of civil religion reaching back to Rousseau is also reflected in the opinion of many of today's researchers. Although BELLAH's book on the USA contains no definition of religion, J. A. COLEMAN gives one, namely that civil religion is "a set of beliefs, rites and symbols which relates a man's role as citizen and his society's place in space, time and history to the conditions of ultimate existence and meaning" (cited by BRYANT 1995: 149). BRYANT adds to this that civil religions must set out the proper relationship between (civil) society and the state in securing a society's place in space, time and history.

The concept of 'political religion' arose in the context of the policy of modernization and nation-building, especially with regard to Africa and the Soviet Union. Christel LANE sees differences between the two kinds of religion. While 'civil reli- 
gion' connects the political order to a transcendent power such as God, 'political religion' simply presents a sacralization of the political order. 'Civil religion' confines itself to the political order, whereas 'political religion' claims authority over all social life (BRYANT 1995: 150). Among other differences, it can be mentioned that in contrast with the historical roots of civil religion, the phenomena of political religion often belong to the area of invented tradition. One can generally agree with the statements of LANE that civil religion is celebrated in societies where the individual is dominant, and political religion where the (party-)state seeks to impose itself (LANE 1981: 44; BRYANT 1995: 150). Civil and political religions include political rituals, 'the rites of rulers'.

\section{RELIGION AND IDENTITY}

Globalization, the general development of the market economy and the collapse of the socialist systems have revived not only the private sphere, but also the question of individual and communal identity, as a contrary process and one occurring principally in a religious and cultural context (KOKOSALAKIS 1993: 136). The uneven secularization of the European societies resulted in a culturally dialectic process between politics and religion, and in the continuous restructuring of religion and the social structure, ethnic and religious identities. There is a tension between the particular and the universal in this process. This is also a central problem of Christianity.

In the wake of Durkheim we can regard the link between religion and identity as axiomatic. Due to the close intertwining of religion and ethnic identity, secularization is less strong in a number of European countries, such as Ireland, Poland, Greece and Malta, than elsewhere in Europe. In multicultural and multireligious regions, religious and ethnic identity may become intertwined. One such region is Ireland where the Catholic religion distinguishes the Irish (CECIL 1993; MACDONALD 1993), or in Moldova, Romania where a section of the Hungarians have become Romanianized in their language but have not abandoned their Catholic religion.

The close intertwining of ethnic and religious identity on the one hand, and ethnic separation on the basis of religion on the other hand can be seen in the Yugoslav conflict. Where those speaking the same language can be distinguished on the basis of religion, they have their own culture and consciousness. Saša NEDELJKOVIĆ speaks in his paper of the link between religious and national identity. He analyses the conflicts in the attitudes towards cosmopolitanization, individualization and the religious/historical traditions present in university life. However, people following the same religion but living in different language communities may differ because of the different cultural background, historical and social factors, or a different interpretation of history. (For example, the differences between Italian and Ukrainian Catholics living in Australia. - LEWINS 1978).

In this way religious and national identity can become intertwined. In certain 
cases religion can help in shaping the nation (e.g. the Rusyns discussed by Bertalan Pusztai in his paper), or in the symbolic expression of a separate ethnic/cultural identity, as in the case of the Roman Catholic Hungarians living in Moldova. Religion is also intertwined with Europeanness. It seems to me that in political life today the political idea of the European Community is in a way a reformulation of the unity constructed (also) on a religious basis in mediaeval Europe. And while the European world is strongly secularized, even if to differing extents in the individual countries, Christianity can nevertheless be found as an ideological support behind the aspirations for European union. But there are debates over whether Europeanness extends to Eastern Christianity, to Orthodoxy, or remains within the confines of Latin Christianity, Roman Catholicism and the Protestant churches which grew out of it, excluding Eastern Christianity from the union. In my opinion there are not only differences of ecclesiastical administration, history, rule, liturgy, etc. between Eastern and Western Christianity but also a different cultural and civilizational background and it would be difficult to bring the two into line. Current official Roman Catholic aspirations stress the overall Europeanness of the two trends. As a symbolical expression of this, in 1981 Pope John Paul II made Cyril and Methodius, too, joint collective patron saints of Europe (ROBERTS 1998: 195-198). This dilemma also finds expression in the proposed process of expansion of the European Union.

Others see in supranational Christianity accepted as the foundation of the European cultures, a force extinguishing and ending national and ethnic specific features. For this reason, in structuring their present national identity and providing it with an ideological underpinning they reach back to reinterpreted and reconstructed forms of pre-Christian local religions and symbols. The use of archaic religious and historical symbols is one of the main ideological tools of the various forms of nationalism. I agree with the study of Agita Misäne and Torunn Selberg: in Europe (Baltic and Scandinavian countries) neo-paganism assumes mainly its Protestant form. I am not able to see clearly why this should be so, since such movements are also present, among others, in Poland and Hungary (WIENCH 1998).

Today's attitude towards life and everyday religious feelings are strongly influenced by the approaching end of the millennium, something experienced by only a few generations in the history of mankind. Opinions and notions in this connection are largely built on religious symbols and ideas of past ages related to the end of the world, the thousand-year reign of Christ and the Last Judgement. People experience a general deterioration of the world in their everyday lives: wars, natural catastrophes, crime, corruption, hostility to the future (=refusal to have children), sexual licentiousness. They see all this as the result of globalization and the individualism that is strengthening parallel with it. Religious and ethnic fundamentalism is appearing as a counteraction. This attitude is often the basis of disillusionment with Christianity and the turning towards pre-Christian cults already mentioned. 
In the opening paper I tried to outline some theoretical questions of the chosen topic of our Conference and its timeliness. What is politics? What is religion? Are there tensions, separation, or interdependence, interference, mutual influence, or co-operation between the two phenomena?

How can the questions raised be answered from the angle of the relations between politics and folk religion? The papers to be presented in the coming days will throw light on many details. However, we can say in general that the similar, symbolical expression of interests and values makes the spheres of politics and religion related fields, and the forms of symbolical expression/behaviour are to a large extent similar or identical. Precisely because of the more or less overlapping fields of interest and values, the forms of symbolical behaviour and the ritualization of actions can also be similar. Moreover, the secular authorities often gain or believe they have gained transcendent legitimation from religion, from the different forms in which religiosity is manifested and, in the final analysis, from reference to God.

On the other hand, examples of the links between national identity and religion show that religion, the religiosity of everyday life, the system of religious symbols, the values represented by religion/denomination have the symbolical power to shape communities, that is, they can join and strengthen people in their self-identities, selfawareness and their sense of communal belonging. In other words, in its operation religion also acquires immediate social/political significance. This is true in everyday religious practice, in the shaping of historical consciousness, and in the interpretation of religious and national conflicts. In both past and present politics and folk religion are interrelated phenomena that permeate and influence each other.

\section{LITERATURE}

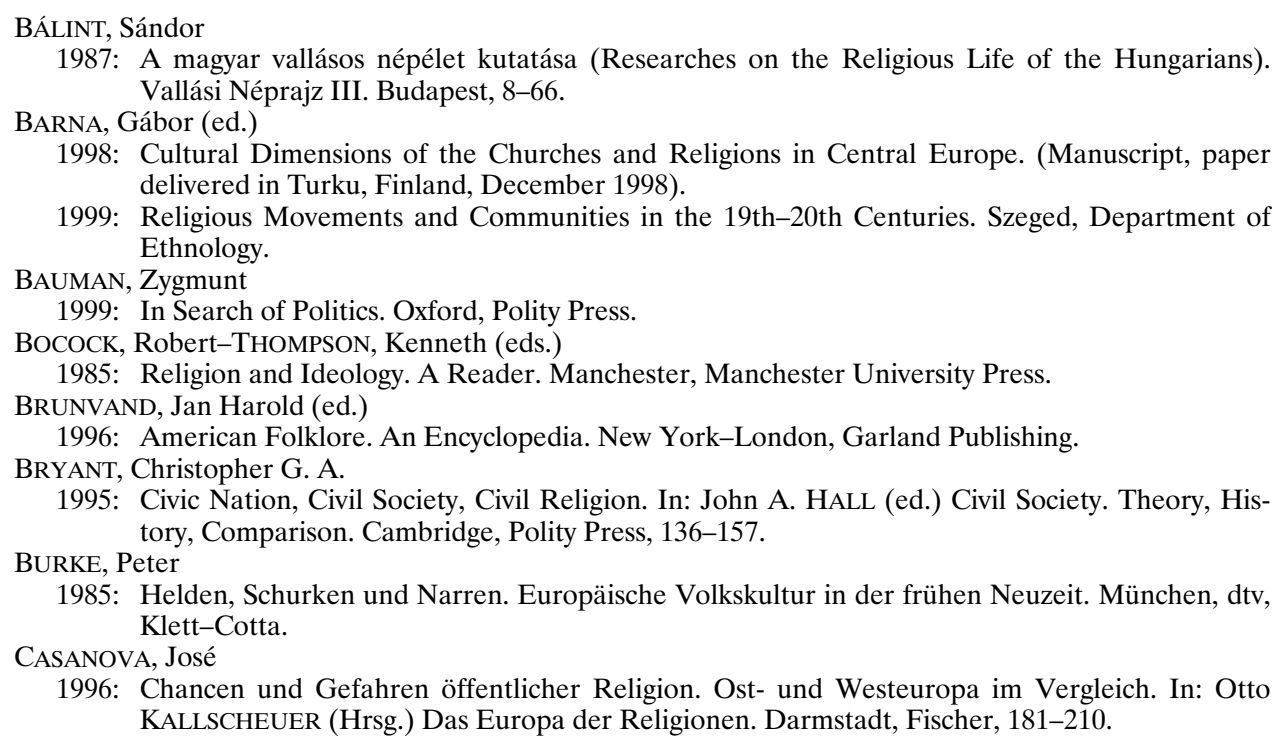




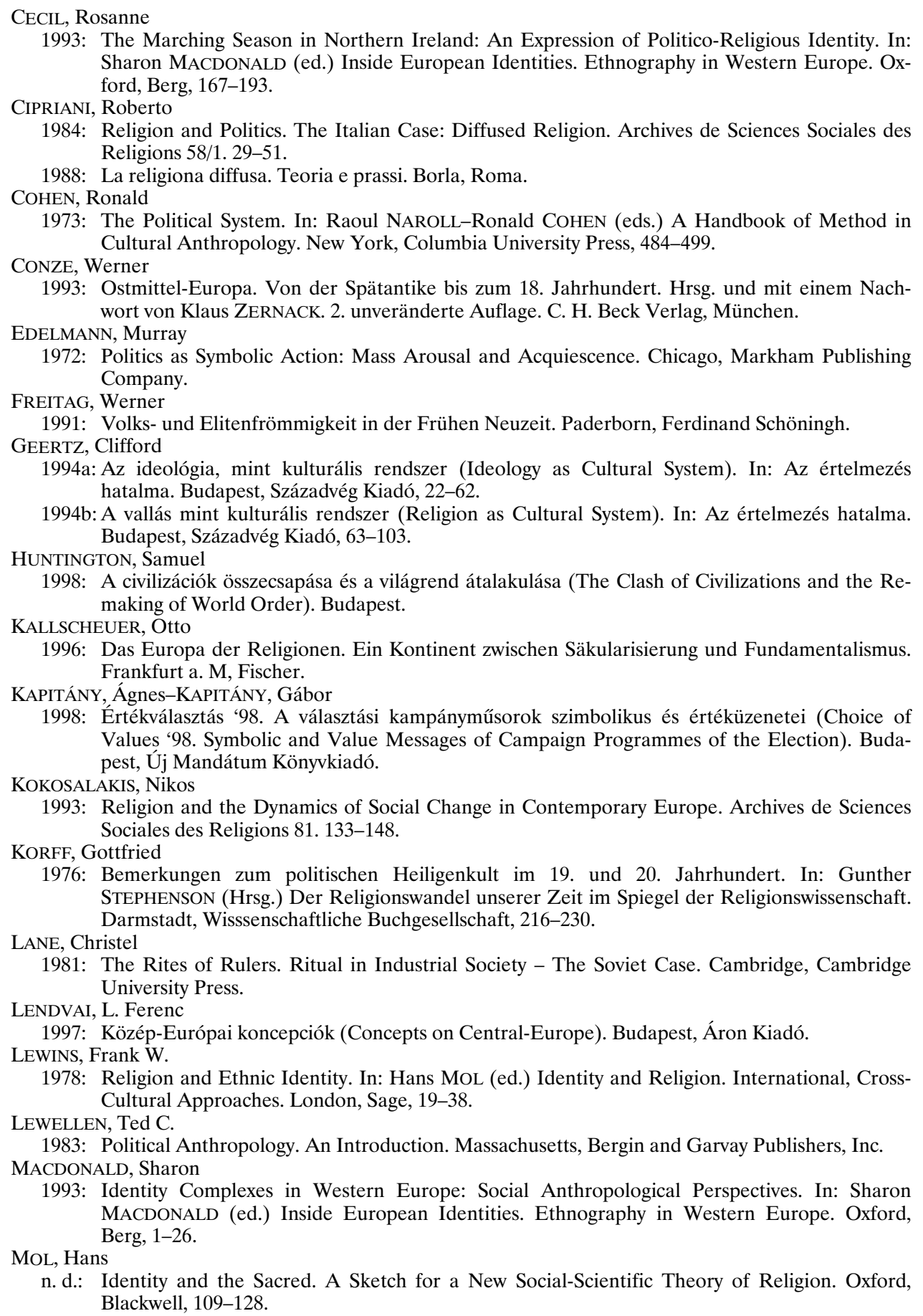


PUszTAI, Bertalan (ed.)

1999: Szent és profán között. (Between the Sacred and the Profane.) Bibliotheca Religionis Popularis Szegediensis 3. Szeged.

RAHNER, K.-MODEHN, Ch.-GÖPFERT, M. (eds.)

1987: Népi vallásosság (Folk Religiosity). OMC Kiadó, Bécs.

ROBERTS, Richard H.

1998: The construals of Europe: Religion, Theology and the Problematics of Modernity. In: Paul HEELAS (ed.) Religion, Modernity and Postmodernity. Blackwell Publishers, Oxford 186-217. SCHIEDER, Rolf

1987. Civil Religion. Die religiöse Dimension der politischen Kultur. Gütersloher Verlagshaus Mohn, Gütersloh.

SZABÓ, Márton

1998: Politikai tudáselméletek (Theories of Political Knowledges). Nemzeti Tankönyvkiadó, Universitas Publisher, Budapest.

SzÛ́CS, Jenó

1983: Vázlat Európa három történeti régiójáról (Sketch on the Three Historical Regions of Europe). Budapest.

TOMKA Mikló

1988: Tendences of Religious Changes in Hungary. Archives de Sciences Sociales des Religions 65/1. 67-79.

1998: A vallásosság mérése (Measuring of Religiosity). In: MÁTHÉ-TóTH, András-JAHN, Mária (eds) Studia Religiosa. Tanulmányok András Imre 70. születésnapjára. Szeged, 18-31.

YODER, Don

1974: Toward the Definition of Folk Religion. Western Folklore 33:2-15.

WIENCH, Piotr

1998: Neopaganism and Ethnic Identity in Central-Eastern Europe. Warsaw (Manuscript).

ZENTAI, Violetta

1997: Politikai antropológia: a politika antropológiája (Political Anthropology: Anthropology of Politics). Budapest, Osiris Kiadó-Láthatatlan Kollégium. 